ACADEMIA ROMÂNĂ
Revine Roumaine de Chimie

\title{
ON THE GREEN CATALYTIC SYNTHESIS OF PURPUROGALLIN
}

\author{
Salima DIB, ${ }^{\mathrm{a}, \mathrm{b}}$ Didier VILLEMIN, ${ }^{\mathrm{a} *}$ Bachir MOSTEFA-KARA, ${ }^{\mathrm{b}}$ Amel HAMHAMI, ${ }^{\mathrm{b}}$ Nathalie BAR, ${ }^{\mathrm{a}}$ \\ Mebrouka DEKHICI ${ }^{\mathrm{a}, \mathrm{c}}$ and Nawel CHEIKH ${ }^{\mathrm{b}, \mathrm{c}}$ \\ a Normandie Université France, ENSICAEN, LCMT, UMR CNRS 6507, INC3 M, FR 3038, Labex EMC3, \\ 6 Bd Maréchal Juin 14050 Caen, France \\ ${ }^{\mathrm{b}}$ Laboratoire de Catalyse et Synthèse en Chimie Organique, Faculté des Sciences, Université de Tlemcen, \\ BP 119,13000 Tlemcen, Algerie \\ ${ }^{\mathrm{c}}$ Faculté de Technologie, Université Tahri Mohamed Béchar, 08000, Bechar, Algérie
}

Received November 4, 2020

The catalytic oxidation under green conditions of pyrogallol into purpurogallin was performed by air with laccase model copper complexes or by plant extracts containing peroxidases in the presence of hydrogen peroxide. A study was conducted for turnip, depending on the amount of extract, the method of introduction and the $\mathrm{pH}$. Optimization of these conditions made it possible to easily obtain pure purpurogallin with a yield of $78 \%$.<smiles></smiles>

\section{INTRODUCTION}

Benzotropolone is a bicyclic polyphenol system with pseudo-aromatic compound properties. The most studied member of this family is purpurogallin a natural red dye found in the bark of oak and gall nuts in the glucoside state. ${ }^{1}$ Purpurogallin is known for its antibacterial, ${ }^{2}$ antioxidant, ${ }^{3}$ anticancer ${ }^{4}$ activities. In addition, purpurogallin can prevent the methylation of hydroxyestradiol by catechol-O-methyltransferase. ${ }^{5}$ It has been shown to specifically prevent the system activation pathway TLR1 / TLR $2{ }^{6}$

The structure of purpurogallin was established by single crystal X-ray analysis ${ }^{1}$ to be a bicyclic molecule comprising a phenolic ring fused with a sevenmembered ring in a highly planar conformation.

Purpurogallin derivatives such as Goupiolone A and $\mathrm{B}$, are known for their significant DNAdamaging activity and were tested for their anticancer activity ${ }^{7,8}$ while Fomentariol isolated from the tree sponge Fomes fomentarius, display anti-oxidant and antidiabetic activities. ${ }^{9}$ Crocipodin is a natural pigment from the fruit bodies of mushroom Leccinum crocipodium. ${ }^{10}$

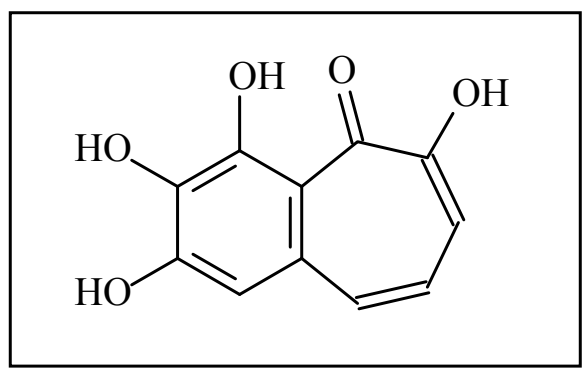

Fig. 1 - Structure of purpurogallin.

\section{EXPERIMENTAL}

\section{Materials and Methods}

All the reactions were carried at room temperature with magnetic stirring and monitored by TLC silica plates. IR spectra were obtained as solids with Fourier transform PerkinElmer. "Spectrum One" with ATR accessory. Only significant absorptions are listed.

\footnotetext{
${ }^{*}$ Corresponding author: didier.villemin@ensicaen.fr
} 


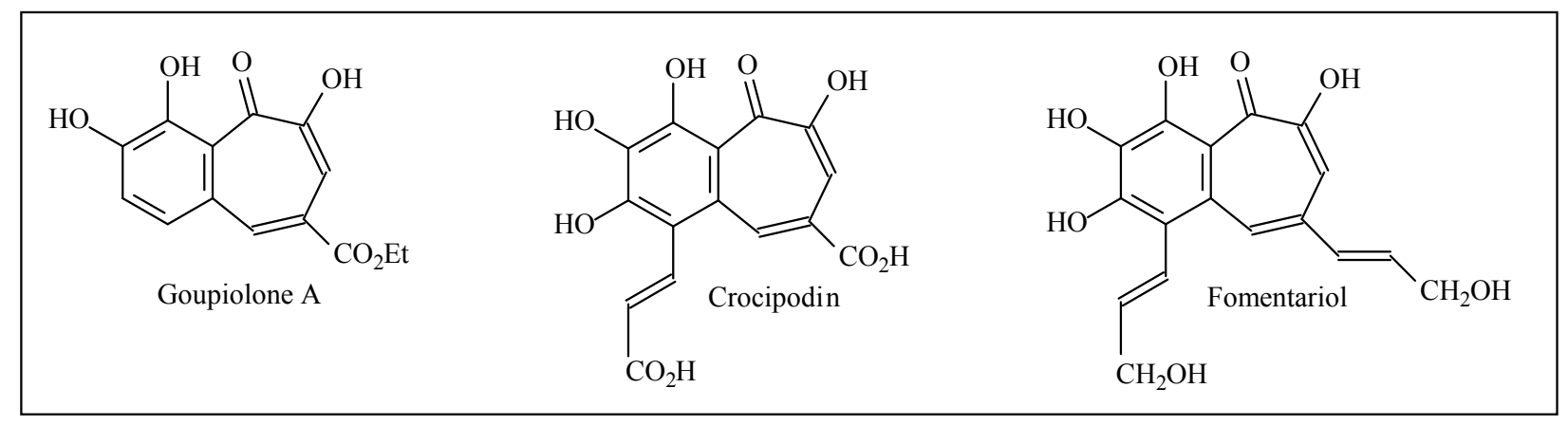

Fig. 2 - Purpurogallin derivatives.

The ${ }^{1} \mathrm{H}$ and ${ }^{13} \mathrm{C}$ NMR spectra were recorded in $\mathrm{CDCl}_{3}$ or DMSO- $\mathrm{d}_{6}$, with a Bruker AC 400 spectrometer. The chemical shifts $\delta$ are expressed in parts per million, conventional abbreviation are used chemical and were referenced to the internal solvent signal namely TMS. Mass spectra were recorded on a QTOF Micro (Waters) spectrometer with electrospray ionization (ESI, positive mode), lock spray PEG.

Horseradish was obtained from a market in France. Red radish (Raphanus sativus var. sativus), Red onion (Allium Cepa), clove garlic (Allium sativum) were purchased from local Market in Tlemcen (Algeria). Bitter turnip or left el mora or left el mahfoura (Brassica rapa L.) was collected from a local farm in west Algeria.

\section{Aerobic oxidation of pyrogallol into purpurogallin using copper catalysts}

The copper complex $[\mathrm{CuClOH} \text { (TMEDA) }]_{2}$ was prepared according to the literature. ${ }^{16}$

A $\mathrm{Cu}$ (I) / PEI suspension was prepared by stirring PEI $(\mathrm{MW}=300,50 \%$ in water $)(0.43 \mathrm{~g}$ of PEI) with cuprous chloride $(5 \mathrm{mmol}, 0.494 \mathrm{~g})$ in $100 \mathrm{~mL}$ of ethanol.

\subsection{Aerobic oxidation catalysed by complex [CuClOH (TMEDA) $]_{2}$}

A mixture of pyrogallol $(504 \mathrm{mg}, 4 \mathrm{mmol})$ and $[\mathrm{CuClOH}$ $($ TMEDA $)]_{2}(74 \mathrm{mg}, 0.16 \mathrm{mmol})$ in ethanol $(20 \mathrm{~mL})$ are stirred in an open flask in the air for 4 days at room temperature. The solid formed is isolated by filtration and recrystallized from acetic acid.

\subsection{Aerobic oxidation catalysed by $\mathrm{Cu}(\mathrm{I}) / \mathrm{PEI}$}

Pyrogallol (504 mg, $4 \mathrm{mmol}$ ) was dissolved in a $\mathrm{Cu}(\mathrm{I}) /$ PEI $(30 \mathrm{~mL})$ suspension and was stirred in an open flask in the air for 4 days at room temperature $\left(20^{\circ}\right)$. The reaction mixture was dissolved in $\mathrm{CH}_{2} \mathrm{Cl}_{2}$, and washed with $10 \%$ aqueous hydrochloric acid solution, the organic phase was dried over $\mathrm{Na}_{2} \mathrm{SO}_{4}$, and evaporated under vacuum. The solid formed is isolated by filtration and recrystallized from acetic acid.

(6E,8Z)-2,3,4,6-tetrahydroxy-5H-benzo[7]annulen-5-one: (Purpurogallin) : deep red needles. Yield 76\%. M.p. $=274-$ $275^{\circ} \mathrm{C} /$ m.p. (lit.) $=275^{\circ} \mathrm{C}{ }^{11}$. FT-IR $\left(\mathrm{cm}^{-1}\right): 3446\left(\mathrm{OH}_{\text {free }}\right)$, $3316\left(\mathrm{OH}_{\mathrm{assoc}}\right), 2925\left(\mathrm{C}-\mathrm{H}_{\mathrm{arom}}\right), 1694(\mathrm{C}=\mathrm{O}) ; 1589 .{ }^{1} \mathrm{H}$ NMR $\delta$ (400 MHz, DMSO d6, ppm): $\delta 15.23(1 \mathrm{H}, \mathrm{s}, \mathrm{OH}), 10.55(1 \mathrm{H}$, s, OH $), 9.40(1 \mathrm{H}, \mathrm{s}, \mathrm{OH}), 9.36(1 \mathrm{H}, \mathrm{s}, \mathrm{OH}), 7.32(1 \mathrm{H}, \mathrm{d}$, $\mathrm{J}=11.2 \mathrm{~Hz}, \mathrm{H} 7), 7.11(1 \mathrm{H}, \mathrm{d}, \mathrm{J}=9.3 \mathrm{~Hz}, \mathrm{H} 9) ; 6.73(1 \mathrm{H}, \mathrm{s}, \mathrm{H} 1)$, $6.72(1 \mathrm{H}, \mathrm{dd}, \mathrm{J}=9.3$ and $11.2 \mathrm{~Hz}, \mathrm{H} 8) ; 13 \mathrm{C}$ NMR $(100 \mathrm{MHz}$, DMSO d6, ppm): $\delta 182.6$ (C5), 155.1 (C6), 152.2 (C2), 151.9 (C4), 135.1 (C3), 134.7 (C9), 133.4 (C10), 124.1 (C8), 116.3 (C7), 115.2 (C11), 110.68 (C1). HRMS: for $\mathrm{C}_{11} \mathrm{H}_{9} \mathrm{O}_{5},(\mathrm{M}+1)$ : calculated mass 221.0450, found 221.0420.

\section{Oxidation of pyrogallol into purpurogallin using vegetables enzymes}

\subsection{Preparation of enzymes extract from Horse radish, Red Radish, Red onion and Garlic}

Vegetables were washed with water then with distillate water. After cautious peeling, they were cut into small pieces and then mixed in cold distilled water $\left(5^{\circ} \mathrm{C}\right)$. The juice obtained was centrifuged (6000 rpm for $12 \mathrm{~min}$ ) then filtered. The solutions used are prepared at different concentrations $(0.2 \mathrm{~g} / \mathrm{mL} ; 0.4 \mathrm{~g} / \mathrm{mL} ; 0.6 \mathrm{~g} / \mathrm{mL})$ relative to the plant material. For the onion and garlic we only used a single concentration of $0.4 \mathrm{~g} / \mathrm{mL}$

\subsection{Enzymes oxidation of pyrogallol into purpurogallin}

Different tests have been carried out depending on the type of enzyme.

* With a solution of $\mathrm{H}_{2} \mathrm{O}_{2}$ (detection of peroxidase)

In a $250 \mathrm{~mL}$ Erlenmeyer flask fitted with a magnetic bar are introduced: pyrogallol ( $1 \mathrm{~g}, 0.008 \mathrm{~mol}), 20 \mathrm{~mL}$ distilled water, a $20 \mathrm{ml}$ hydrogen peroxide solution $(0.147 \mathrm{M})$ and $20 \mathrm{~mL}$ of a solution of vegetable extract per $5 \mathrm{~mL}$ portion every $30 \mathrm{~min}$.

The reaction mixture was stirred for $12 \mathrm{~h}$ to $16 \mathrm{~h}$ at room temperature, and then the precipitate formed was filtered and washed with cold distilled water $\left(5-10^{\circ} \mathrm{C}\right)$. More products were recovered by treating the filtrate by extraction with ethyl acetate.

* Without $\mathrm{H}_{2} \mathrm{O}_{2}$ solution (detection of tyrosinase and laccase)

In this synthesis the same steps previously described were followed except that no hydrogen peroxide was added.

\section{Extraction of bitter turnip and purpurogallin syntheses:}

A systematic study, taking into account various parameters, was carried out for this bitter turnip, in order to optimize yields. The same procedures for the preparation of vegetable extracts and the synthesis of purpurogallin were adopted.

\subsection{Variations in the turnip extract concentration}

The same steps for preparing turnip extracts were used. Solutions of $0.2 \mathrm{~g} / \mathrm{mL}, 0.3 \mathrm{~g} / \mathrm{mL}, 0.4 \mathrm{~g} / \mathrm{mL}, 0.5 \mathrm{~g} / \mathrm{mL}$ and $0.6 \mathrm{~g} / \mathrm{mL}$ were used at the $\mathrm{pH}$ of distilled water.

The synthesis of purpurogalline was carried out for 18 hours, at room temperature, the pyrogallol $(1 \mathrm{~g}, 0.008 \mathrm{~mol})$ dissolved in $20 \mathrm{~mL}$ of distilled water, the hydrogen peroxide solution $(20 \mathrm{~mL}, 0.147 \mathrm{M})$ and the different concentrations of turnip extract. The precipitate obtained is filtered and washed with cold distilled water. We obtain for each case the 
purpurogallin in solid form with variable yields (11-25\%) presented in Table 1.

Table 1

Optimization of concentration of turnip extract

\begin{tabular}{c|c}
\hline Concentration $\mathrm{g} / \mathrm{mL}$ & Yield \% \\
\hline 0.2 & 11 \\
0.3 & 15 \\
0.4 & 25 \\
0.5 & 25 \\
0.6 & 11 \\
\hline
\end{tabular}

\subsection{Variation of the time and frequency of introduction} of bitter turnip extract and $\mathrm{H}_{2} \mathrm{O}_{2}$ solutions

In an Erlenmeyer flask fitted with a magnetic bar dissolved the pyrogallol $(1 \mathrm{~g}, 0.008 \mathrm{~mol})$ in $20 \mathrm{ml}$ of distilled water. The solutions of $\mathrm{H}_{2} \mathrm{O}_{2}(0.147 \mathrm{M})$ and turnip extract $(0.4 \mathrm{~g} / \mathrm{mL})$ were added:

* Method 1: every 2 hours for 6 hours $(3 \times 20 \mathrm{~mL}$ of $\mathrm{H}_{2} \mathrm{O}_{2}+3 \times 20 \mathrm{~mL}$ of turnip extract)

* Method 2: every hour for 6 hours $\left(6 \times 10 \mathrm{~mL}\right.$ of $\mathrm{H}_{2} \mathrm{O}_{2}$ $+6 \times 10 \mathrm{~mL}$ of turnip extract)

* Method 3: every 30 minutes for 6 hours $(12 \times 5 \mathrm{~mL}$ of $\mathrm{H}_{2} \mathrm{O}_{2}+12 \times 5 \mathrm{~mL}$ of turnip extract)

Purpurogallin was obtained with yields varying between $25 \%$ and $36 \%$ Table 2 .

Table 2

Optimisation of introduction methodology of hydrogen peroxide solution

\begin{tabular}{c|c}
\hline Method 1 & Yield $=34 \%$ \\
Method 2 & Yield $=\mathbf{3 6 \%}$ \\
Method 3 & Yield $=25 \%$ \\
\hline
\end{tabular}

\subsection{Change in the pH of the bitter turnip extract solution}

Depending on the $\mathrm{pH}$ ranges, buffer solutions was prepared using $0.1 \mathrm{~N}$ hydrochloric acid, $0.1 \mathrm{~N}$ citrate, $\mathrm{KH}_{2} \mathrm{PO}_{4}$ $(9.078 \mathrm{~g} / \mathrm{L})$ and $\mathrm{Na}_{2} \mathrm{HPO}_{4}(11.875 \mathrm{~g} / \mathrm{L})$ solutions.
The vegetable extract was prepared in these buffer solutions (20 g in $50 \mathrm{~mL}$ of buffer solution) with a concentration of $0.4 \mathrm{~g} / \mathrm{mL}$.

The synthesis of purpurogallin was carried out according to method 2 described above. Purpurogallin was obtained with yields ranging from $20-78 \%$ Table 3 .

\section{RESULTS AND DISCUSSION}

One molecule of purpurogallin was formed by the oxidation of two molecules of pyrogallol.

The purpurogallin formation mechanism involves the coupling of two aromatic nuclei followed by the opening of one of the rings by oxidation and then the formation of the tropolone nucleus as highlighted by Haworth. ${ }^{11}$

Oxidases are also capable of oxidizing pyrogallol to purpurogallin, such as laccase, ${ }^{12}$ tyrosinase, ${ }^{13}$ peroxidases (from horseradish (HRP) ${ }^{14}$ from Ginkgo, ${ }^{15}$ from Agaricus bisporus mushroom $^{16}$ ) using oxygen from the air or hydrogen peroxide as oxidants.

Although purpurogallin can be obtained from stoichiometric oxidation of pyrogallol with potassium iodate ${ }^{17}$ or potassium ferricyanide as oxidant. These old methods are not very clean and the purification processes are quite tedious, so, a green catalytic reaction is desirable.

So we have studied two approaches:

An aerobic process that mimic laccase using air as an oxidant and a copper catalyst.

A process using vegetable peroxidases close to HRP, readily available, using hydrogen peroxide as an oxidant.

\section{Table 3}

Optimization of $\mathrm{pH}$ with the bitter turnip extracts solution

\begin{tabular}{c|c|c|c|c|c|c|c|c}
\hline $\mathrm{pH}$ & 2.6 & 3.36 & 4.15 & 5.57 & 6.21 & 6.97 & 7.7 & 8.36 \\
\hline Yield \% & 20 & 24 & 26 & 49 & $\mathbf{7 8}$ & 54 & 52 & 39 \\
\hline
\end{tabular}

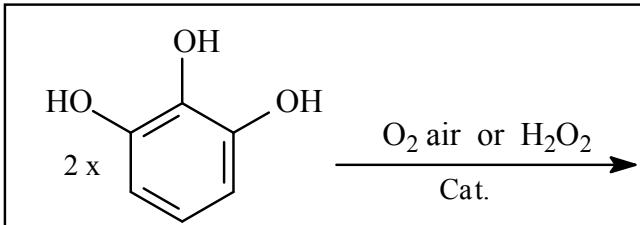

Pyrogallol

Cat. $=$ Copper Complex or Vegetables Extracts<smiles>O=C([O-])[CH+]1CC=Cc2cc(O)c(O)c(O)c2C1=O</smiles>

Purpurogallin 
Table 4

Oxidation of pyrogallol into purpurogallin in the presence of copper catalysts.

\begin{tabular}{c|c|c|c}
\hline Catalyst & Solvent & $\mathrm{T}^{\circ} \mathrm{C}$ & Yield (\%) \\
\hline$[\mathrm{CuCl}(\mathrm{OH}) \text { TMEDA }]_{2}[\mathbf{a}]$ & EtOH & 20 & 43 \\
$\mathrm{Cu}(\mathrm{I}) / \mathrm{PEI}[\mathbf{b}]$ & EtOH & 20 & 0 \\
{$[\mathrm{CuCl}(\mathrm{OH}) \mathrm{TMEDA}]_{2} / \mathrm{NHPI}[\mathbf{c}]$} & $\mathrm{CH}_{3} \mathrm{CN}$ & 70 & 0 \\
\hline
\end{tabular}

Conditions: reagent $\left(2.10^{-3} \mathrm{~mol}\right)$, [a] cat $[\mathrm{CuCl}(\mathrm{OH}) \mathrm{TMEDA}]_{2}(8 \% \mathrm{~mol}), 20^{\circ} \mathrm{C}$, EtOH $(25 \mathrm{ml}),[\mathrm{b}] \mathrm{cat} \mathrm{Cu}(\mathrm{I}) / \mathrm{PEI}$, $20^{\circ} \mathrm{C}$, EtOH $(25 \mathrm{ml})$, [ c] cat $[\mathrm{CuCl}(\mathrm{OH}) \mathrm{TMEDA}]_{2}(8 \% \mathrm{~mol}) / \mathrm{NHPI}(10 \%), 70^{\circ} \mathrm{C}, \mathrm{CH}_{3} \mathrm{CN}, 96 \mathrm{~h}$.

Table 5

Comparison of vegetable activities in the synthesis of purpurogallin

\begin{tabular}{c|c|c|c|c|c}
\hline Vegetable & Horse radish & Red radish & Red onion & Garlic & Bitter turnip \\
\hline $\begin{array}{c}\text { Concentration } \\
\mathrm{g} / \mathrm{mL}\end{array}$ & 0.4 & 0.4 & 0.4 & 0.4 & 0.4 \\
\hline $\mathrm{pH}$ & 5.2 & 5.2 & 5.2 & 5.2 & 6.21 \\
\hline $\begin{array}{c}\text { Yield }(\%) \\
\text { With } \mathrm{H}_{2} \mathrm{O}_{2} \\
\text { Without } \mathrm{H}_{2} \mathrm{O}_{2}\end{array}$ & 14 & 13 & 14 & 30 & 78 \\
\hline
\end{tabular}

(a) Purpurogallin was obtained with a better yield without using an $\mathrm{H}_{2} \mathrm{O}_{2}$ solution

(b) The oxidation product of pyrogallol without $\mathrm{H}_{2} \mathrm{O}_{2}$ was a green solid

\section{Aerobic oxidation catalysed by copper complex as model of laccase}

Laccase is known to catalyse the oxidation of pyrogallol. $^{12}$ It is an oxidase containing copper atoms in its active oxidation site. Moreover a number of copper-amine complexes are known to mimic laccase. ${ }^{18}$ One of the most active complexes is the copper complex with tetramethylethylene diamine $^{19}[\mathrm{CuCl}(\mathrm{OH}) \mathrm{TMEDA}]_{2}$. We have used this complex in the aerobic coupling of naphthol to binaphthol ${ }^{20}$ or spiro derivatives. ${ }^{21}$ PEI-copper in the laboratory has similar properties in many oxidations of phenols. ${ }^{22} \mathrm{We}$ tested the effectiveness of the two $[\mathrm{CuCl}(\mathrm{OH}) \mathrm{TMEDA}]_{2}$ and $\mathrm{Cu}(\mathrm{I}) / \mathrm{PEI}$ catalysts in the synthesis of purpurogallin by aerobic oxidation of pyrogallol. The reactions were carried out in ethanol at room temperature $\left(20^{\circ} \mathrm{C}\right)$. We also studied the possibility of pyrogallol oxidation in the presence of $\mathrm{N}$ Hydroxylphtalimide (NHPI) in acetonitrile at $70^{\circ} \mathrm{C} .^{23-25}$ The results are presented in table 4 .

The tests for the oxidation of pyrogallol to purpurogallin, reported in Table 4, show that the $\mathrm{Cu}$ (I)/PEI and the $[\mathrm{CuCl}(\mathrm{OH}) \mathrm{TMEDA}]_{2} / \mathrm{NHPI}^{20}$ mixture do not catalyse the oxidation reactions of pyrogallol.

\section{Enzymatic oxidation by vegetables extracts}

Peroxidases are known to oxidize pyrogallol into purpurogallin in the presence of hydrogen peroxide as an oxidant. $^{14}$ The best known is horseradish peroxidase (HRP) found in horseradish and related brassicas.

In order to compare and optimize the yields of the oxidation reaction, we used other vegetable extracts like: red radish (Brassica rapa, var.sativa), red onion (Allium Cepa), clove garlic (Allium sativum) and bitter turnip (left el mora or left el mahfoura (Brassica rapa, var. Arabum) as a source of enzymes. Garlic (Allium sativum) is also known to contain peroxidase, ${ }^{26}$ it has shown interesting oxidative activity on pyrogallol. The results are presented in Table 5 .

Horseradish and red radish gave the expected results, although in our case with horseradish extract, we did not adjust the $\mathrm{pH}$ of solution.

Red onion and garlic extracts showed oxidative activity both in the presence of $\mathrm{H}_{2} \mathrm{O}_{2}$ (presence of peroxidases), and without $\mathrm{H}_{2} \mathrm{O}_{2}$ solution (presence of other oxidases).

We chose the bitter turnip, the most active, to conduct a study with different parameters: concentration of vegetable extract (variation in the mass of the plant material), time and frequency of introduction of the vegetable extract and the $\mathrm{H}_{2} \mathrm{O}_{2}$ solution, $\mathrm{pH}$ of the vegetable extract solution.

For the bitter turnip, we optimized the conditions of concentration and acidity and at $\mathrm{pH}=6.21$ we obtained a maximum yield of $78 \%$ (See experimental part). 


\section{CONCLUSIONS}

Two efficient green catalytic oxidation approaches to the synthesis of purpurogallin from pyragallol are reported. The first was the aerobic oxidation catalysed by the copper complex $[\mathrm{CuCl}(\mathrm{OH}) \mathrm{TMEDA}]_{2}$. A second approach was the used of vegetable extract as source of peroxidase with hydrogen peroxide as oxidant. Oxidation with extracts of bitter turnips gives a good yield with a simplified purification method.

Acknowledgments. The authors wish to thank DGRST/MESRS (Ministère de l'Enseignement Supéreur et de la Recherche Scientifique) from Algeria for the financial support. We gratefully acknowledge financial support from the" Ministère de la Recherche et des Nouvelles Technologies", "CNRS (Centre National de la Recherche Scientifique)". The authors wish also to thank Mrs Karine Jarsale for the HRMS analysis.

\section{REFERENCES}

1. T. W. Wu, L. H. Zeng, J. Wu, K. P. Fung, R. D. Weisel, A. Hempel and N. Camermans, Biochem. Pharmacol., 1996, 52, 1073-1080.

2. Y. Inamori, C. Muro, E. Sajima, M. Katagiri, Y. Okamoto, H. Tanaka, Y. Sakagami and H. Tsujibo, Biosci. Biotech. Biochem., 1997, 61, 890-892.

3. H. Sugiyama, K. P. Fung and T. W. Wu, Life Sci., 1993, 53, 39-43.

4. Y. Pommier and M. Cushman, Molec. Cancer Therapeutics, 2009, 8, 1008-1014.

5. J. D. Lambert, D. Chena, C. Y. Wang, N. Ai, S. Sang, C. T. Ho, W. Welsh and C. Yang, Bioorg. and Med. Chem., 2005, 13, 2501-2525.

6. K. Cheng, X. Wang, S. Zhang and H. Yin, Angewandte Chem. Int. Edition, 2012, 124, 12412-12415.

7. N. Fukui, K. Ohmori and S. Keisuke, Helvetica Chem. Acta, 2012, 95, 2194-2197.
8. Y. Matsuo, A. Yoshida, Y. Saito and T. Tanaka, Angewandte Chem. Int. Edition, 2017, 56, 11855-11859

9. N. Maljuric, J. Golubovic, M. Ravnikar, D. Zigon, B. Strukelj and B. Otasevic, J. Anal. Methods in Chem., 2018, 2018, article ID 2434691.

10. L. Kerschensteiner, F. Löbermann, W. Steglich and D. Trauner, Tetrahedron, 2011, 67, 1536-1539.

11. A. Crithlow, E. Haslam, R. D. Haworth, P. B. Tinker and N. M. Waldron, Tetrahedron, 1967, 23, 2829-2847.

12. J. J. Roy and T. E. Abraham, J. Chem. Tech. Biotechn., 2006, 81, 1836-1839.

13. H. Tauber, Proceed. of the Soc. for Experim. Biol. and Med., 1952, 81, 237-240.

14. D. A. Converso and M. E. Fernández, Phytochemistry, 1995, 40, 1341-1345.

15. S. Park, Bull. of Korean Chem. Soc., 2006, 27(11), $1885-1887$.

16. H. Gouzi and A. Benmansour, Int. J. Chem. Reactor Eng., 2007, 5, 1542.

17. T. W. Evans and W. M. Dehn, J. Am. Chem. Soc., 1930, 52, 3647-3649.

18. S. E. Allen, R. R. Walvoord, R. Padilla-Salinas and M. C. Kozlowski, Chem. Rev., 2013, 113, 6234-6458.

19. T. Punniyamurthy and L. Rout, Coord. Chem. Rev., 2008, 252, 134-154.

20. P. A. Jaffrès, N. Bar and D. Villemin, J. Chem. Soc., Perkin I, 1998, 2083-2090.

21. M. Dekhici, S. Plihon, N. Bar, D. Villemin, N. Elsiblani and N. Cheikh, Chemistry Select, 2019, 4, 705-708.

22. M. Dekhici, "Activation aérobie et biomimétique de liaison $\mathrm{C}-\mathrm{H}$ des phénols catalysée par les complexes cuivre-amines", $P h D$ thesis, University of Caen, 2014, http://www.these.fr/2014CAEN2041.

23. F. Minisci, C. Punta, F. Recupero, F. Fontana and G. F. Pedulli, J. Org. Chem., 2002, 67, 2671-2676.

24. Y. Ishii and S. Sakaguchi, Catalysis Surveys from Asia, 1999, 3, 27-35.

25. A. K. Shibamoto, S. Sakaguchi and Y. Ishii, Organic Process Research and Development, 2000, 4, 505-508.

26. S. El Ichi-Ribault, A. Miodek, H. Dorizon, J. P. Mahy, C. Henry, M. N. Marzouki and H. Korri-Youssoufi, Eur. J. Biochem., 2010, 16, 157-72. 
